\title{
The first records of Senecio inaequidens along motorways in Poland and Slovakia
}

Petr Kocián

The first records of Senecio inaequidens along motorways in Poland and Slovakia. - Acta Mus. Siles. Sci. Natur. 65: 129-133, 2016.

\begin{abstract}
The paper reports on finds of the invasive species Senecio inaequidens along motorways in Poland and Slovakia. The species was already mentioned in the floras of both countries but until recently there had been no reports from motorways there. In 2015, a large population of Senecio inaequidens was found along the A4 motorway in Poland. In 2013, it was collected along the D2 motorway in Slovakia. Intensive road traffic is probably the main vector of Senecio inaequidens invasion along motorways in Central Europe. Motor vehicles can carry the propagules over long distances. The newly recorded sites along the A4 in Poland and the D2 in Slovakia are part of the species' invasion eastwards. It is assumed that Senecio inaequidens will continue to spread along motorways in both countries and in the region as a whole.
\end{abstract}

Key words: Senecio inaequidens, invasive species, motorway, Poland, Slovakia.

\section{Introduction}

Senecio inaequidens DC., a perennial herb native to South Africa, was introduced into Europe at the end of the 19th century and successfully invaded considerable parts of Western and Central Europe in the last quarter of the 20th century. The history and patterns of this invasion are very well known and described (e.g. Ernst 1998, Heger \& Böhmer 2005, 2006). In Germany, the species has been spreading eastwards along railway lines and motorways since the 1970s (e.g. Böhmer 2002, Radkowitsch 2003). In the past three decades, besides the invasion along railways, the fast and long-distance spreading along the motorways of Central Europe has been quite remarkable. At the beginning of its Central European "motorway invasion", the German motorway network was the first to be invaded in the 1980s and 1990s (e.g. Griese 1996, Radkowitsch 2003, Heger \& Böhmer 2005). Following, records of Senecio inaequidens along motorways outside of Germany started to be reported from Switzerland (Stecher \& Buckelmüller 2012), Austria (Hohla 2001, 2011) and the Czech Republic (Joza 2008, Kocián 2014). Until recently, Senecio inaequidens had not been reported from motorways in Poland and Slovakia, although the species was already mentioned in the floras of both countries (cf. Tokarska-Guzik et al. 2012, Kwiatkowski \& Zając 2014 for Poland; Jehlík 1998, Feráková 2002 for Slovakia). This article reports the first records of Senecio inaequidens along motorways in Poland and Slovakia.

\section{Materials and methods}

Data were collected from 2013 to 2015 while travelling along motorways in Slovakia and Poland. The following sections of motorways were mapped in both directions at a speed of $90 \mathrm{~km} / \mathrm{h}$ : the section of the A4 from Wrocław to Gliwice in Poland and the section of the D2 from the CZ/SK border to Malacky in Slovakia. Mapping grids in Poland correspond to the ATPOL grid system (Zając 1978). Mapping grids in Slovakia correspond to the Central European floristic mapping system (Slavík 1971). Mapping units are linear sections of the motorways and are based on motorway distance markers; the basic mapping unit is 1.0 motorway kilometre in Poland and 0.5 motorway kilometre in Slovakia. The GPS coordinates for each mapping unit are measured in the centre of these mapping units. Coordinates are given in WGS-84. Abundance levels (AL) are indicated as follows: (AL1) - one to several plants, (AL2) - scattered clusters of plants, (AL3) - numerous, linear population. Parts of the motorways 
are indicated as follows: CR - central reservation, RS - road shoulder. Collected herbarium specimens are deposited as indicated in the Herbarium of the Department of Botany and Zoology, Faculty of Science, Masaryk University, Brno (BRNU) and the Herbarium of Muzeum Novojičínska, Nový Jičín (NJM).

\section{Results}

\section{Senecio inaequidens along motorways in Poland}

In Poland, Senecio inaequidens was reported for the first time from Katowice in 1987 (Ernst 1998) and its invasion there has been related to railway lines (cf. Kwiatkowski \& Zając 2014). It is considered locally established in the flora of Poland (Tokarska-Guzik et al. 2012). Until recently there had been no reports from motorways. In 2015, Senecio inaequidens was recorded in rather high numbers along the A4 motorway (motorway section Wrocław Bielany - Gliwice Kleszczów) between the $168.0 \mathrm{~km}$ and $195.0 \mathrm{~km}$ distance markers. It occurs there in the central reservation with about hundreds individuals. Senecio inaequidens must have been present along the A4 motorway for a longer time, as it had developed nearly continuous populations along this section stretching out over about $23 \mathrm{~km}$. Moreover, a single plant was discovered further eastwards on the A4 motorway (by the $239.0 \mathrm{~km}$ distance marker) near Prószków.
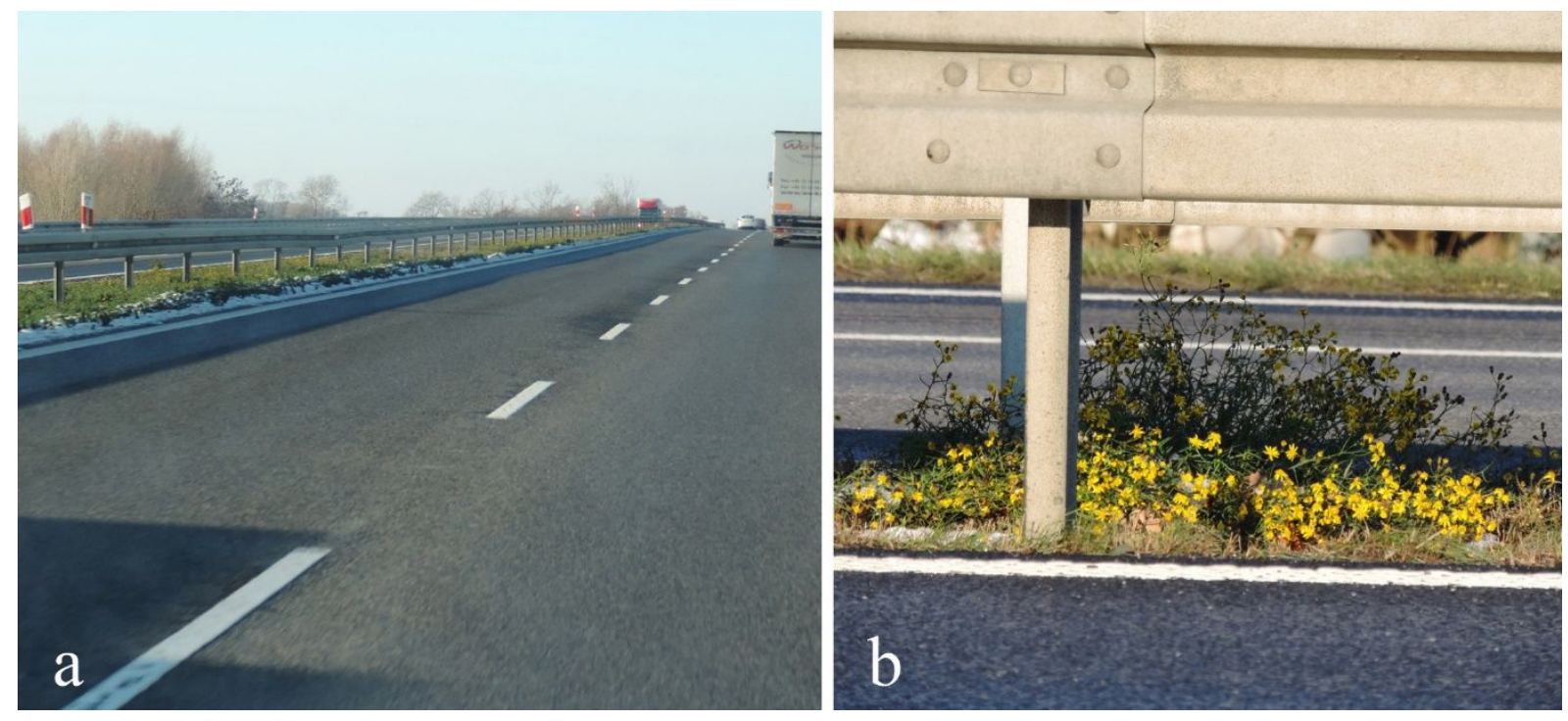

Fig 1: Senecio inaequidens in Poland: a - linear population in the central reservation along the A4 motorway between the 175.0 and $176.0 \mathrm{~km}$ distance markers (24. XI. 2015), b - flowering plant in the central reservation on the A4 motorway between the 184.0 and $185.0 \mathrm{~km}$ distance markers (24. XI. 2015). Photo by Petr Kocián.

Tab 1: Senecio inaequidens along the A4 motorway, in the direction of Gliwice.

\begin{tabular}{|c|c|c|c|c|c|c|}
\hline ATPOL & Location & Part & GPS & Abundance & Altitude & Date \\
\hline BE69 & $168.0-169.0 \mathrm{~km}$ & $\mathrm{CR}$ & $50^{\circ} 56^{\prime} 33.816^{\prime \prime} \mathrm{N}, 17^{\circ} 5^{\prime} 50.517^{\prime \prime} \mathrm{E}$ & AL2 & 135 & 9. XI. 2015 \\
\hline BE69 & $171.0-172.0 \mathrm{~km}$ & $\mathrm{CR}$ & $50^{\circ} 55^{\prime} 28.760^{\prime \prime} \mathrm{N}, 17^{\circ} 7^{\prime} 42.125^{\prime \prime} \mathrm{E}$ & AL1 & 139 & 9. XI. 2015 \\
\hline BE69 & $172.0-173.0 \mathrm{~km}$ & $\mathrm{CR}$ & $50^{\circ} 55^{\prime} 4.635^{\prime \prime N}, 17^{\circ} 820.992^{\prime \prime E}$ & AL1 & 139 & 9. XI. 2015 \\
\hline CE70 & $174.0-175.0 \mathrm{~km}$ & $\mathrm{CR}$ & $50^{\circ} 54^{\prime} 22.127^{\prime \prime} \mathrm{N}, 17^{\circ} 9^{\prime} 37.669^{\prime \prime} \mathrm{E}$ & AL1 & 142 & 9. XI. 2015 \\
\hline CE70 & $175.0-176.0 \mathrm{~km}$ & $\mathrm{CR}$ & $50^{\circ} 54^{\prime} 0.693 " \mathrm{~N}, 17^{\circ} 10^{\prime} 18.125^{\prime \prime} \mathrm{E}$ & AL3 & 145 & 9. XI. 2015 \\
\hline CE70 & $176.0-177.0 \mathrm{~km}$ & $\mathrm{CR}$ & $50^{\circ} 53^{\prime} 38.719^{\prime \prime} \mathrm{N}, 17^{\circ} 10^{\prime} 56.208^{\prime \prime} \mathrm{E}$ & AL1 & 146 & 9. XI. 2015 \\
\hline CE70 & $177.0-178.0 \mathrm{~km}$ & $\mathrm{CR}$ & $50^{\circ} 53^{\prime} 14.982^{\prime \prime} \mathrm{N}, 17^{\circ} 11^{\prime} 28.045^{\prime \prime} \mathrm{E}$ & AL1 & 147 & 9. XI. 2015 \\
\hline CE70 & $180.0-181.0 \mathrm{~km}$ & $\mathrm{CR}$ & $50^{\circ} 51^{\prime} 57.279^{\prime \prime} \mathrm{N}, 17^{\circ} 13^{\prime} 4.616^{\prime \prime} \mathrm{E}$ & AL3 & 144 & 9. XI. 2015 \\
\hline CE70 & $182.0-183.0 \mathrm{~km}$ & $\mathrm{CR}$ & $50^{\circ} 51^{\prime} 5.251^{\prime \prime} \mathrm{N}, 17^{\circ} 14^{\prime} 4.019^{\prime \prime} \mathrm{E}$ & AL2 & 139 & 9. XI. 2015 \\
\hline CE70 & $184.0-185.0 \mathrm{~km}$ & $\mathrm{CR}$ & $50^{\circ} 50^{\prime} 33.794^{\prime \prime} \mathrm{N}, 17^{\circ} 15^{\prime} 32.172^{\prime \prime} \mathrm{E}$ & AL2 & 141 & 9. XI. 2015 \\
\hline CE81 & $190.0-191.0 \mathrm{~km}$ & CR & $50^{\circ} 48^{\prime} 21.764^{\prime \prime} \mathrm{N}, 17^{\circ} 19^{\prime} 3.668^{\prime \prime} \mathrm{E}$ & AL2 & 154 & 9. XI. 2015 \\
\hline CE81 & $191.0-192.0 \mathrm{~km}$ & $\mathrm{CR}$ & $50^{\circ} 47^{\prime} 54.669^{\prime \prime} \mathrm{N}, 17^{\circ} 19^{\prime} 28.619^{\prime \prime} \mathrm{E}$ & AL3 & 164 & 9. XI. 2015 \\
\hline CE81 & $193.0-194.0 \mathrm{~km}$ & $\mathrm{CR}$ & $50^{\circ} 47^{\prime} 5.230^{\prime \prime} \mathrm{N}, 17^{\circ} 20^{\prime} 37.066^{\prime \prime} \mathrm{E}$ & AL2 & 160 & 9. XI. 2015 \\
\hline CE81 & $194.0-195.0 \mathrm{~km}$ & $\mathrm{CR}$ & $50^{\circ} 46^{\prime} 44.814^{\prime \prime} \mathrm{N}, 17^{\circ} 21^{\prime} 14.840^{\prime \prime} \mathrm{E}$ & AL2 & 160 & 9. XI. 2015 \\
\hline CF04 & $238.0-239.0 \mathrm{~km}$ & $\mathrm{CR}$ & $50^{\circ} 34^{\prime} 4.035^{\prime \prime} \mathrm{N}, 17^{\circ} 51^{\prime} 47.282^{\prime \prime} \mathrm{E}$ & AL1 (1 ex.) & 174 & 24. XI. 2015 \\
\hline
\end{tabular}




\section{Senecio inaequidens along motorways in Slovakia}

In Slovakia, Senecio inaequidens was first found in the inland port of Komárno in 1997 (Jehlík 1998) and one year later in Bratislava (Feráková 2002). The most recent records come from the railway station in Rimavská Sobota (Eliáš jun. 2015), a gravel pit near Dunajská Lužná, and Trstín limestone quarry (Košt'ál 2012, 2015). The species is classified as casual in the flora of Slovakia (Medvecká et al. 2012). Until recently there had been no reports of Senecio inaequidens from motorways. In 2013, it was collected along the D2 motorway in the direction of Bratislava (motorway section CZ/SK border - Malacky) between the 2.0 and $2.5 \mathrm{~km}$ distance markers (leg. P. Kocián, herb. BRNU, NJM). Later in 2015, more plants were found at this locality and new localities were found elsewhere along the D2 motorway. It occurs there along a gravel road shoulder and in the central reservation.

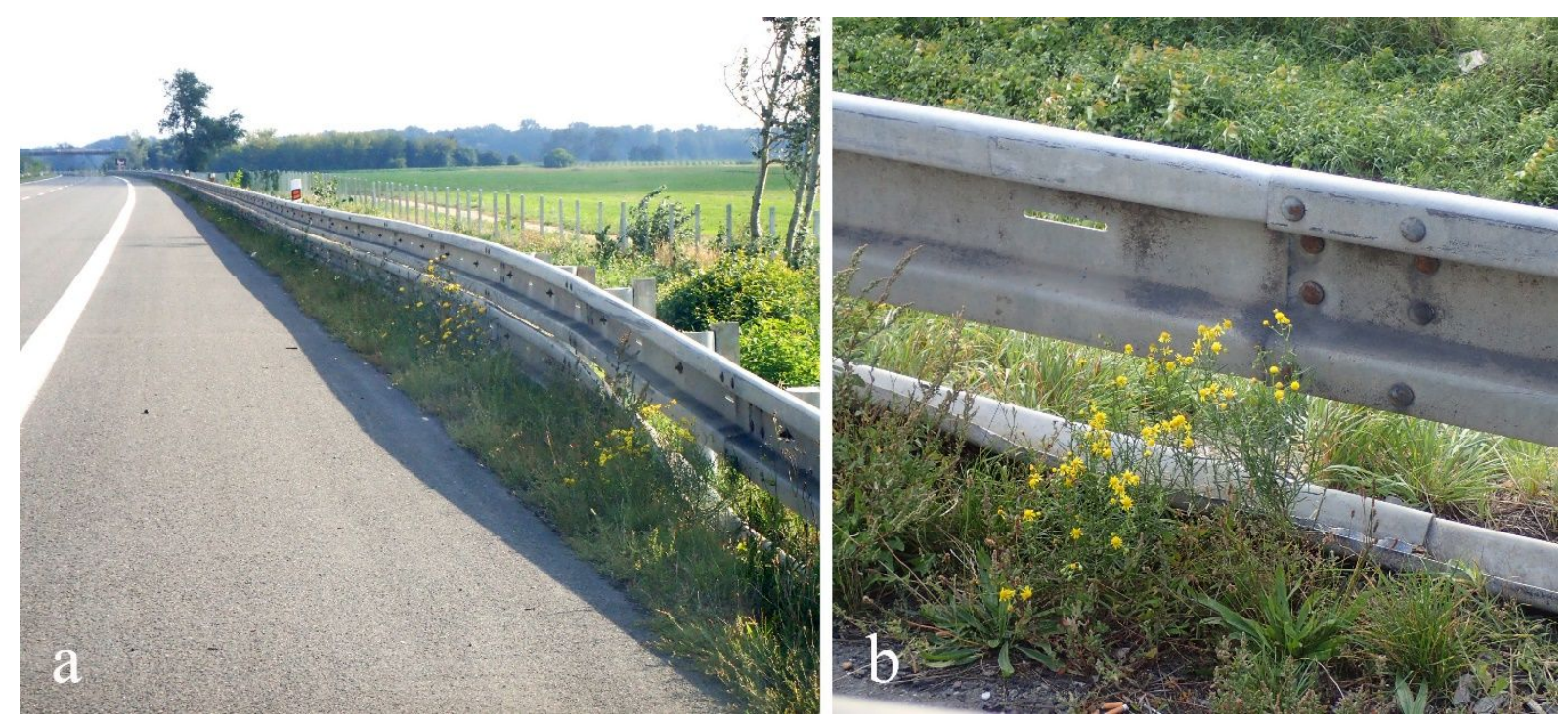

Fig 2: Senecio inaequidens in Slovakia: a - scattered plants along the road shoulder on the D2 motorway between the 2.0 and $2.5 \mathrm{~km}$ distance markers (12. IX. 2015), b - detail of a flowering plant along the road shoulder on the D2 motorway between the 2.0 and $2.5 \mathrm{~km}$ distance markers (12. IX. 2015). Photo by Petr Kocián.

Tab 2: Senecio inaequidens along the D2 motorway, in the direction of Bratislava.

\begin{tabular}{|c|c|c|c|c|c|c|}
\hline CEFMS & Location & Part & GPS & Abundance & Altitude & Date \\
\hline $7367 \mathrm{~b}$ & $2.0-2.5 \mathrm{~km}$ & RS & $48^{\circ} 39^{\prime} 58.519^{\prime \prime} \mathrm{N}, 16^{\circ} 59^{\prime} 22.935^{\prime \prime} \mathrm{E}$ & AL1 (1 ex.) & 150 & 13. X. 2013 \\
\hline $7367 b$ & $2.0-2.5 \mathrm{~km}$ & $\mathrm{RS}$ & $48^{\circ} 39^{\prime} 58.519^{\prime \prime} \mathrm{N}, 16^{\circ} 59^{\prime} 22.935^{\prime \prime} \mathrm{E}$ & AL1 (4 ex.) & 150 & 12. IX. 2015 \\
\hline $7367 \mathrm{~b}$ & $2.5-3.0 \mathrm{~km}$ & $\mathrm{RS}$ & $48^{\circ} 39^{\prime} 42.200^{\prime \prime} \mathrm{N}, 16^{\circ} 59^{\prime} 27.300^{\prime \prime} \mathrm{E}$ & AL1 (2 ex.) & 150 & 12. IX. 2015 \\
\hline $7368 \mathrm{c}$ & $6.0-6.5 \mathrm{~km}$ & $\mathrm{CR}$ & $48^{\circ} 37^{\prime} 54.306^{\prime \prime} \mathrm{N}, 17^{\circ} 0 \prime 21.335^{\prime \prime} \mathrm{E}$ & AL1 (1 ex.) & 150 & 12. IX. 2015 \\
\hline
\end{tabular}

\section{Discussion}

Senecio inaequidens becomes very apparent along motorways especially in the period from September to November because of its yellow flowering heads and "shrubby" appearance, so that it can be easily distinguished while travelling by car at normal speed. It is also one of the last flowering plants along motorways of the season. This is due to the long flowering period (it flowers from July to November) and its ability to recover after mowing of the roadside vegetation.

Intense international road transport in Central Europe after the turn of the millennium is probably the main vector for some invasive species that spread along motorways in the region. One of these plants (sometimes called "motorway plants") is Senecio inaequidens that has lately been reported from motorways in Austria and the Czech Republic. Until recently, there had been no records of Senecio inaequidens along motorways in Poland and Slovakia. The newly recorded sites along the A4 motorway in Poland might be a result of intensive road traffic using 
this road while heading from France/Belgium/Germany eastwards, as the A4 motorway is part of the European E-class road E40 connecting Western Europe with Eastern Europe. Considering the traffic directions, the history of the species invasion in Central Europe, intensive road transport and the relative closeness of the German populations, it seems likely that Senecio inaequidens is already present along some motorways in other parts of Poland (e.g. the A2, A4, A6 motorways), especially near the border with Germany and has remained unnoticed by botanists. In Slovakia, the sites of Senecio inaequidens along the D2 motorway are clearly an extension of its range along the D1/D2 motorway in the Czech Republic (the Czech D2 motorway is followed up by the Slovak D2 motorway at the CZ/SK border). On the D2 motorway in Slovakia, Senecio inaequidens was found along motorway lanes which are used by traffic heading from (Praha-) Brno towards Bratislava (in south-eastern direction). Moreover, there is a quite large population (about 50 plants) on the Czech D2 motorway (by the $45.0 \mathrm{~km}$ distance marker near the village of Ladná) just some $17 \mathrm{~km}$ (a 9-minute drive) to the nearest site of Senecio inaequidens on the D2 motorway in Slovakia. The propagules could therefore have originated from this nearby site or from sites further along the D1/D2 motorway in the Czech Republic.

\section{Conclusion}

Senecio inaequidens was found for the first time along motorways in Poland and Slovakia, continuing its "motorway invasion" in Central Europe. It is assumed that the invasion will continue along motorways in both countries and in the region as a whole. Motorways provide effective dispersal corridors and the spread of Senecio inaequidens along the motorways is promoted mainly by intensive road traffic. Preliminary data from a survey in the eastern part of the Czech Republic ( $c f$. Kocián 2014) show that motorways might have become the primary invasion routes for Senecio inaequidens while it is continuing to expand its range eastwards in Central Europe. However, it is too early to draw definitive conclusions. Collection of more relevant data will be necessary. Therefore, a more thorough survey of the motorways in the Czech Republic, Poland and Slovakia is planned for the next years.

\section{References}

Böhmer H.J. (2002): Das Schmalblättrige Greiskraut (Senecio inaequidens DC. 1837) in Deutschland - eine aktuelle Bestandsaufnahme. - Florist. Rundbr. 25: 47-54.

Eliáš P. jun. (2015): Senecio inaequidens. - In: Eliáš P. jun. (ed.): Zaujímavejšie floristické nálezy. - Bull. Slov. Bot. Spoločn. 37: 230.

Ernst W.H.O. (1998): Invasion, dispersal and ecology of the South African neophyte Senecio inaequidens in the Netherlands: from wool alien to railway and road alien. - Acta Bot. Neerl. 47: 131-151.

Feráková V. (2002): Nové lokality zriedkavých neofytov flóry Slovenska. - Bull. Sloven. Bot. Spol. 24: 113116.

Griese D. (1996): Zur Ausbreitung von Senecio inaequidens DC. an Autobahnen in Nordostdeutschland. Braunschw. Naturkdl. Schr. 5: 193-204.

Heger T. \& Böhmer H.J. (2005): The invasion of Central Europe by Senecio inaequidens DC. - A complex biogeographical problem. - Erdkunde 59: 34-49.

- (2006): NOBANIS - Invasive Alien Species Fact Sheet - Senecio inaequidens. Online Database of the European Network on Invasive Alien Species - NOBANIS [online]. [cit. 16. 10. 2013]. Available from: http:// www.nobanis.org.

Hohla M. (2001): Dittrichia graveolens (L.) W. Greuter, Juncus ensifolius Wikstr. und Ranunculus penicillatus (Dumort.) Bab. neu für Österreich und weitere Beiträge zur Kenntnis der Flora des Innviertels und des angrenzenden Bayerns. — Beitr. Naturk. Oberösterreichs 10: 275-353.

- (2011): Zwei Funde der Kleinen Seerose (Nymphaea candida) sowie weitere Beiträge zur Kenntnis der Flora von Oberösterreich. - Stapfia 95: 141-161.

Jehlík V. (1998): Senecio inaequidens a Atriplex heterosperma - nové invazní rostliny také na Slovensku, p. 23. In: Eliáš P. (ed.): Invázie a invázne organizmy (Abstrakty a program 2. vedeckej konferencie Nitra, 18. - 20. november 1998). Slovenský národný komitét SCOPE \& Katedra ekológie FZKI SPU Nitra, Nitra, 37 pp. 
Joza V. (2008): Přehled výskytu starčku úzkolistého (Senecio inaequidens) v České republice. - Muz. a Součas., ser. natur. 23: 201-210.

Kocián P. (2014): První nálezy invazního starčku úzkolistého (Senecio inaequidens) na dálnicích a rychlostních silnicích Moravy a Slezska (Česká republika). - Acta Carp. Occ. 5: 46-55.

Košt'ál J. (2012): Senecio inaequidens. - In: Eliáš P. jun. (ed.): Zaujímavejšie floristické nálezy. - Bull. Slov. Bot. Spoločn. 34: 110.

Koštál J. (2015): Senecio inaequidens. - In: Eliáš P. jun. (ed.): Zaujímavejšie floristické nálezy. - Bull. Slov. Bot. Spoločn. 37: 233.

Kwiatkowski P. \& Zając R. (2014): Nowe stanowisko Senecio inaequidens (Asteraceae) w południowej Polsce. - Fragm. Florist. Geobot. Polon. 21 (1): 27-40.

Medvecká J., Kliment J., Májeková J., Halada L., Zaliberová M., Gojdičová E., Feráková V. \& Jarolímek I. (2012): Inventory of the alien flora of Slovakia. - Preslia 84: 257-309.

Radkowitsch A. (2003): Neophytic plants in Bavaria (Senecio inaequidens and Dittrichia graveolens), pp. 4761. In: Zajac A., Zajac M. \& Zemanek B. (eds): Phytogeographical problems of synanthropic plants. Institute of Botany, Jagiellonian University, Cracow, 354 pp.

Slavík B. (1971): Metodika sít’ového mapování ve vztahu k připravovanému fytogeografickému atlasu ČSR. Zpr. Čs. Bot. Společ. 6: 55-62.

Stecher R. \& Buckelmüller J. (2012): Eine gebietsfremde Pflanze auf dem Vormarsch. Das Schmalblättrige Greiskrau. - Umweltpraxis 69: 19-20.

Tokarska-Guzik B., Dajdok Z., Zając M., Zając M., Urbisz A., Danielewicz W. \& Hołdyński C. (2012): Rosliny obcego pochodzenia w Polsce ze szczególnym uwzglednieniem gatunków inwazyjnych. Generalna Dyrekcja Ochrony Srodowiska, Warszawa, 197 pp.

Zając A. (1978): Atlas of distribution of vascular plants in Poland (ATPOL). - Taxon 27: 481-484.

Author's address: Petr Kocián, Nerudova 5, CZ-74101 Nový Jičín, Czech Republic.

E-mail: petr.kocian@kvetenacr.cz 